\title{
Inadequate diagnostic value of the water-drinking test
}

\section{J. A. ROTH}

Department of Experimental Ophthalmology, Institute of Ophthalmology, University of London

There is a large literature on the subject of the water-drinking test. Many authors have evaluated it and considered it to be a reliable method of diagnosing chronic simple glaucoma (Agarwal and Sharma, I953; Bloomfield and Kellerman, I947; Nørskov, 1967; Scheie, Spencer, and Helmick, I956; Swanljung and Blodi, I956).

Leydhecker (I950a, b, I954) found the test unreliable with Schiötz tonometry. Becker and Gay (1959) and Drance (1963) found it to be reliable with applanation rather than indentation tonometry. Lawrence and Wolff (1962) found no significant difference in their results when both methods were used, but preferred applanation tonometry for other reasons.

The inaccuracy of Schiötz tonometry in the water-drinking test has been ascribed to changes in scleral rigidity resulting from uptake of water by the ocular tissues (Becker and Gay, 1959; Drance, 1960, r963; Galin, Aizawa, and McLean, I961), but no alteration in scleral rigidity was found by Saiduzzafar (1962) and Stepanik (1958).

Most authors have agreed that a rise in intraocular pressure (IOP) of $6 \mathrm{~mm}$. $\mathrm{Hg}$ is suggestive of the presence of chronic simple glaucoma, but opinions have varied as to what is to be considered as a truly pathological rise (Table I).

Table I Suspicious and pathological rises in tension

\begin{tabular}{|c|c|c|c|}
\hline Author & Date & $\begin{array}{l}\text { Suspicious rise } \\
(\mathrm{mm} . \mathrm{Hg})\end{array}$ & $\begin{array}{l}\text { Pathological rise } \\
(\mathrm{mm} . \mathrm{Hg})\end{array}$ \\
\hline Blaxter & 1956 & 6 & $8-9$ \\
\hline Bloomfield and Kellerman & I 947 & 6 & $6+($ Schiötz $)$ \\
\hline Drance & 1963 & & $\begin{array}{l}5 \text { (Schiötz) } \\
7 \text { (Applanation) }\end{array}$ \\
\hline Evans & 1942 & & 8 (Schiötz) \\
\hline Galin and others & 1965 & & 6 (Applanation) \\
\hline Lawrence and Wolff & 1962 & 6 & 7 (Both) \\
\hline Leydhecker & I 954 & 6 & 9 or to over 30 (Schiötz) \\
\hline Nørskov & 1967 & & 8 (Applanation) \\
\hline Sugar & 1948 & & 9 or to over 33 (Schiötz) \\
\hline
\end{tabular}


The timing of the maximum rise in IOP after the ingestion of water is also a source of disagreement (Table II), but Spaeth (1967) pointed out that it was impossible to predict the timing.

Table II Timing of maximum rise in tension (minutes after ingestion of $\left.\mathrm{H}_{2} \mathrm{O}\right)$

\begin{tabular}{|c|c|c|}
\hline Author & Date & Time (min.) \\
\hline Bietti & I 972 & $25-35$ \\
\hline Drance & I 963 & $10-20$ \\
\hline Norskov & I967 & $15-3^{0}$ \\
\hline Yonebayashi & I $95^{8}$ & $20-30$ \\
\hline
\end{tabular}

Spaeth (1967) and Bietti (1972) objected to the method whereby all patients had to drink I litre of water regardless of body weight. Spaeth suggested that greater reliability would result from a water load adjusted to the body weight of the patient and gave as an example a figure of $\mathrm{I}_{4} \mathrm{ml} . \mathrm{H}_{2} \mathrm{O} / \mathrm{kg}$. Bietti recommended a solution of 5 per cent. glucose be given intravenously at a loading of $5 \mathrm{ml}$. $\mathrm{kg}$. weight.

If the test is useful it should be able to distinguish between normal eyes and those with glaucoma or with ocular hypertension, or those in which glaucoma is suspected but not confirmed by other methods. It was therefore decided to review water-drinking test results on a series of well-documented patients with diagnosis confirmed by other methods.

\section{Methods}

The notes of every patient who had been subjected to the water-drinking test at the Glaucoma Clinic at the Institute of Ophthalmology during the 3-year period before November, 1972, were studied. Some notes were rejected for various reasons:

(a) The patient was unable to drink a litre of water (2 patients).

(b) The patient vomited after drinking (2 patients).

(c) The patients had narrow angles and might have given a rise in pressure through angle closure.

(d) Patients who had previously had drainage operations.

All patients whose notes were selected for study were well documented. Gonioscopy had been done at least once. All had had detailed examination of the optic discs, and many had serial photographs taken of the discs. All had open angles on gonioscopy. Detailed visual field studies had been done on every patient by at least two methods, usually the Globuch screen and the static version of the Goldmann perimeter described by Gloster (1970). None of the patients had received treatment.

All patients had had hourly tensions recorded from 9.30 to I I.30 a.m. at the clinic in the nonfasting state on a separate occasion. Ocular tensions were measured by applanation tonometry.

In the review of the notes the diagnoses were based on the material described above-not on the results of the water-drinking tests. 


\section{Diagnostic categories}

\section{(I) NOT GLAUCOMA}

Patients referred to the Glaucoma Clinic but found to have ocular tensions not higher than 2 I $\mathrm{mm}$.

Hg during phasing.

No visual field loss.

Normal optic discs.

\section{(2) OGULAR HYPERTENSION}

Discs and fields as above.

Ocular tensions higher than 2 I $\mathrm{mm}$. $\mathrm{Hg}$ recorded on one or more occasions.

\section{(3) GLAUCOMA SUSPECT}

Either the appearance of the optic discs and/or the results of visual field tests were suspicious of glaucoma irrespective of intraocular pressure.

\section{(4) CHRONIC SIMPLE GLAUCOMA}

Definite glaucomatous change in both the optic disc and visual field. This included four eyes with low tension glaucoma.

The protocol of the water-drinking test was as follows:

Patients were instructed to fast from midnight the night before the test, so that the test was performed after fasting for at least 9 hours. Tensions were recorded on arrival, and the patients then given I litre of water to drink as rapidly as possible within so minutes. Tensions were recorded at is minute intervals subsequently and in most cases up to an hour after drinking the water but in a few recording was stopped after 45 minutes.

\section{Results}

Results from phasing and water-drinking tests are summarized in Table III. Eyes have been divided into diagnostic categories and mean tensions and standard deviations have been calculated for each group and for all eyes together.

Table III Results in diagnostic categories

\begin{tabular}{|c|c|c|c|c|c|c|c|c|c|}
\hline \multirow{2}{*}{ Diagnosis } & \multirow{2}{*}{$\begin{array}{l}\text { No. } \\
\text { of } \\
\text { eyes }\end{array}$} & \multicolumn{2}{|c|}{$\begin{array}{l}\text { Phasing tension } \\
(\mathrm{mm} . \mathrm{Hg})\end{array}$} & \multicolumn{5}{|c|}{ Water-drinking test tension $(\mathrm{mm} . \mathrm{Hg})$} & \multirow{2}{*}{$\begin{array}{l}\text { Rise } \\
\text { in } \\
\text { tension } \\
(\mathrm{mm} . \\
\mathrm{Hg})\end{array}$} \\
\hline & & $9 \cdot 3^{0}$ & 10.30 & Fasting & I 5 & $3^{0}$ & 45 & $\begin{array}{l}60 \text { min. after } \\
\text { ingestion }\end{array}$ & \\
\hline Not glaucoma & $4^{I}$ & I6(3) & I $8(3)$ & I $7(3)$ & $20(4)$ & $2 \mathbf{I}(4)$ & I $9(4)$ & I $9(3)$ & $4(2)$ \\
\hline Glaucoma & 64 & $23(3)$ & $22(3)$ & $22(3)$ & $26(4)$ & $28(4)$ & $26(4)$ & $25(6)$ & $6(3)$ \\
\hline Ocular hypertension & 74 & $22(5)$ & $23(5)$ & $2 \mathrm{I}(5)$ & $27(6)$ & $29(7)$ & $27(7)$ & $28(8)$ & $9(3)$ \\
\hline Glaucoma suspect & $3 \mathrm{I}$ & $2 \mathrm{I}(4)$ & $23(4)$ & $20(4)$ & $25(5)$ & $26(5)$ & $25(5)$ & $24(6)$ & $7(3)$ \\
\hline All & 210 & $2 \mathrm{I}(5)$ & $22(4)$ & $2 \mathrm{I}(4)$ & $25(6)$ & $26(6)$ & $25(6)$ & $25(7)$ & $7(3)$ \\
\hline
\end{tabular}

Mean results recorded to nearest $\mathrm{mm}$. $\mathrm{Hg}$ S.D. to nearest whole number (in brackets).

Fig. I (overleaf) shows the distribution of rises in tension in each group and Fig. 2 the course of events during the water-drinking test compared with tensions observed during phasing (the latter are shown as dotted lines). 


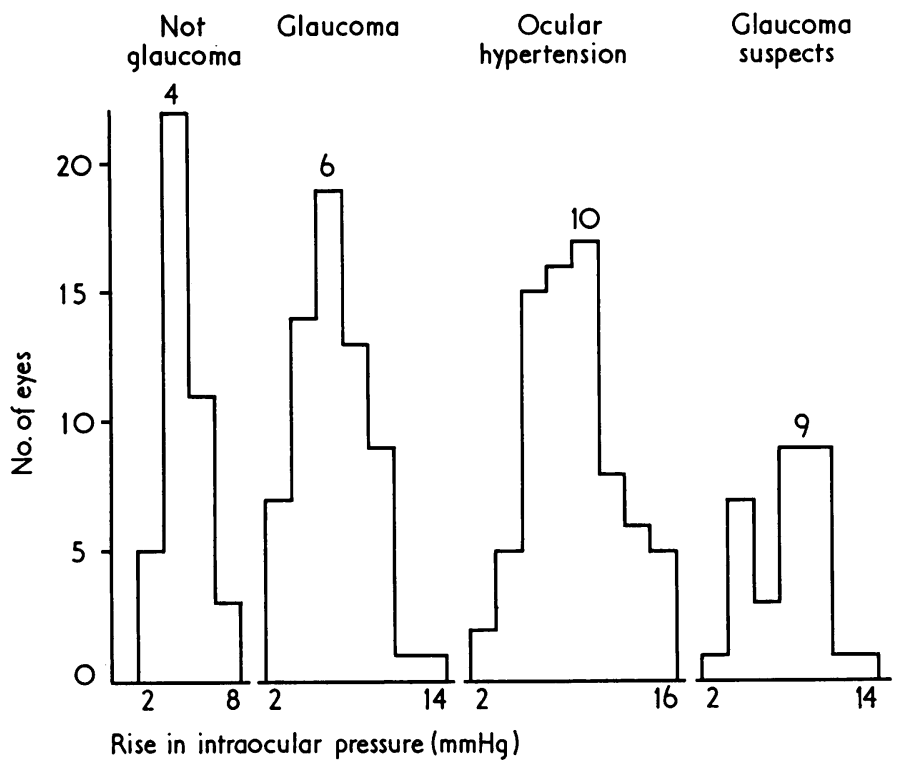

FIG. I Distribution of rise in tension in different diagnostic categories

The majority of eyes had the maximum rise in tension at 30 minutes after drinking water and this occurred in all groups.

The results were subjected to further statistical analysis.

Coefficients of correlation were calculated to relate initial (fasting) tension to the rise in tension produced by drinking water (Table IV).

Table IV Coefficients of correlation

\begin{tabular}{ll}
\hline Diagnosis & $\begin{array}{l}\text { Coefficients of correlation } \\
(\text { tension and rise in tension })\end{array}$ \\
Not glaucoma & $0 \cdot 1 \mathbf{1}$ \\
Glaucoma & $0 \cdot 03$ \\
Ocular hypertension & $0 \cdot 30$ \\
Glaucoma suspect & $0 \cdot 24$ \\
All eyes & $0 \cdot 26$ \\
\hline
\end{tabular}

None of these figures show a significant correlation.

Student ' $t$ ' tests were done to determine whether the results obtained from each group were significantly different from each other.

\section{Initial tension}

All groups were tested against each other.

The highest level of significance was between NOT GLAUCOMA and GLAUGOMA where $\mathrm{P}<0 \cdot 05$.

Rise in tension

All groups were tested against each other.

The highest levels of significance were between NOT GLAUCOMA and GLAUCOMA SUSPECT $\mathrm{P}<0 \cdot 04$ and from NOT GLAUCOMA and GLAUCOMA. 

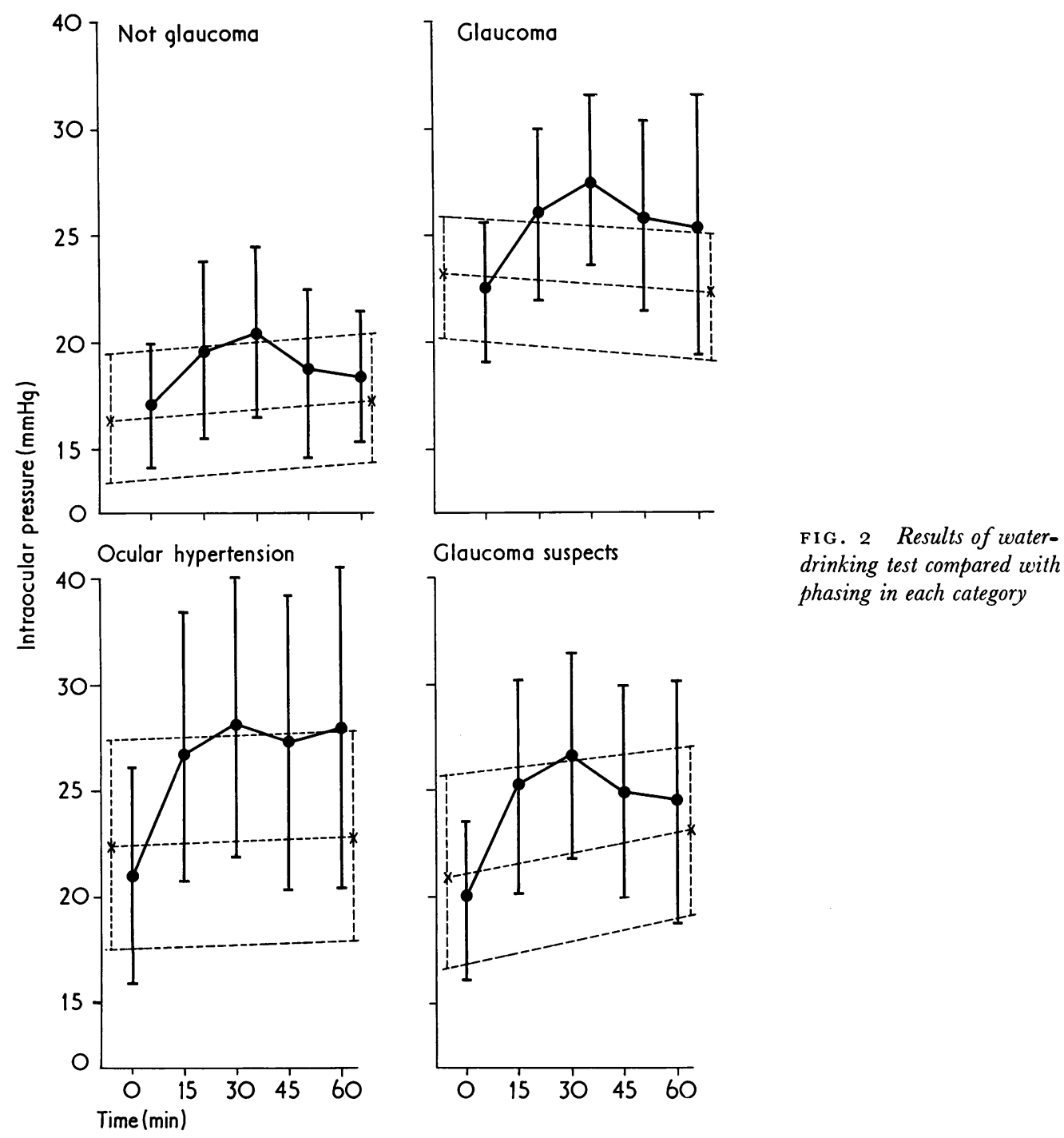

\section{Discussion}

It is agreed by most authors (see Introduction) that a rise of $6 \mathrm{~mm}$. $\mathrm{Hg}$ or more during the water-drinking test is suggestive of the presence of chronic simple glaucoma.

Using this criterion the highest proportion of positive tests was obtained in eyes with ocular hypertension ( 82 per cent.), the next in glaucoma suspects ( 74 per cent.), followed by glaucoma ( $5^{2}$ per cent.), and then by normals ( 22 per cent.) (Table V).

Table V Proportions of positive water-drinking tests in each group

\begin{tabular}{|c|c|c|c|}
\hline Diagnosis & No. of eyes & $\begin{array}{l}\text { No. of eyes with rise } \\
\text { in tension of } 6 \mathrm{~mm} . \mathrm{Hg} \\
\text { or more }\end{array}$ & $\begin{array}{l}\text { Percentage } \\
\text { positive } \\
\text { tests }\end{array}$ \\
\hline Not glaucoma & $4 \mathrm{I}$ & 9 & 22 \\
\hline Glaucoma & 64 & 33 & $5^{2}$ \\
\hline Ocular hypertension & 74 & 61 & 82 \\
\hline Glaucoma suspect & $3^{1}$ & 23 & 74 \\
\hline
\end{tabular}


Thus a rise of not more than $6 \mathrm{~mm}$. $\mathrm{Hg}$ during the test cannot be said to exclude glaucoma nor can a greater rise be said to confirm its presence.

This agrees fairly well with Blaxter (1956), who stated that 60 per cent. of eyes with early glaucoma may have a negative response to the water-drinking test and with Leydhecker (I 950a) who found 42 per cent. negative tests in chronic simple glaucoma.

It is evident from the figures produced in this study that the highest rises in tension occurred in the ocular hypertension group, with glaucoma suspects falling between chronic simple glaucoma and ocular hypertension. Thus glaucoma suspects cannot be distinguished from either group and there is no clear division between patients with confirmed glaucoma and ocular hypertension on the basis of the water-drinking test.

Swanljung and Blodi (1956) stated that the water-drinking test was 70 per cent. reliable in that it was positive in 70 per cent. of patients with chronic simple glaucoma. In the present study it would be as true to state that it was 82 per cent. reliable in the detection of ocular hypertension and only $5^{2}$ per cent. reliable in glaucoma.

A number of eyes in the glaucoma suspect group also had ocular hypertension ( 9 of $3 \mathrm{I}$ eyes-approximately $6 \mathrm{I}$ per cent.). If these are added to the ocular hypertension group there is a total of 93 eyes of which 83 had rises in tension of $6 \mathrm{~mm}$. $\mathrm{Hg}$ or more. Thus 88 per cent. of eyes with ocular hypertension had positive water-drinking test results.

It could be argued that a proportion of the patients diagnosed as ocular hypertension and glaucoma suspects in this study will sooner or later develop glaucoma and that they should be treated prospectively. A recent study by Perkins (1973) has shown that in a 5-year follow-up of patients with ocular hypertension and/or suspicious optic discs and/or a positive family history of glaucoma, 3.5 per cent. developed chronic simple glaucoma. In the present study ro5 eyes fall into these categories so it is likely that over a similar period only four or five eyes will develop glaucoma.

There appears to be little correlation between initial tension and the rise produced by provocation (see Table IV) either in any one group or in all groups taken together. Thus a high initial tension may not be linked to a positive result in the water-drinking test. The highest correlation was in ocular hypertension $(0 \cdot 30)$ but even this is low.

In Table I there are references to tensions of $30 \mathrm{~mm}$. Hg or more (Leydhecker, I954) and $33 \mathrm{~mm}$. $\mathrm{Hg}$ or more (Sugar, I948) during the water-drinking test as being pathological. In the present study rises to these levels did not occur in the group defined as not glaucoma. Whilst pressure readings of $30 \mathrm{~mm}$. $\mathrm{Hg}$ were not uncommon in eyes with confirmed glaucoma, they occurred in many eyes with ocular hypertension.

There was no significant difference between fasting and non-fasting tensions recorded at 9.30 a.m. It may be that the relative dehydration of the patient before the waterdrinking test is irrelevant and adds little to the value of the procedure.

The water-drinking test cannot be said to be reliable as a diagnostic procedure. There is a false positive rate of 22 per cent. in normal eyes and a false negative rate of 48 per cent. in eyes with confirmed chronic simple glaucoma. If ocular hypertension were always followed by overt chronic simple glaucoma then the test would be reliable, but this is not the case. There is some factor common to a high proportion of eyes with ocular hypertension and glaucoma which makes them respond to the water-drinking test with rises of tension of $6 \mathrm{~mm}$. $\mathrm{Hg}$ or more, but the nature of this factor is unknown.

\section{Conclusion}

The water-drinking test cannot be used to separate the four categories described and is therefore of very limited value as a provocative test for chronic simple glaucoma. 
The eyes could be divided into diagnostic categories without taking into account the results of the water-drinking test. One must agree with Richardson (1972) that there is no "magic number" one can use to distinguish diagnostic groups and that an accurate diagnosis of glaucoma depends upon meticulous methodical examination of the eye.

The water-drinking test is therefore not worth doing as a diagnostic procedure.

\section{Summary}

The value of the water-drinking test as a provocative test for chronic simple glaucoma was assessed by examining its effects on a group of patients who had been divided into diagnostic categories on the basis of data derived from other methods of examination.

It was concluded that the water-drinking test is of little or no diagnostic value.

I am grateful to Dr. J. Gloster for permission to examine patients under his care. I should like to thank Mr. D. Poinoosawmy and Mr. D. G. Parry for their assistance and Mr. B. Augier for the statistical analyses.

\section{References}

Agarwal, L. P., and sharma, C. K. (1953) Brit. F. Ophthal., 37, 330

BECKER, B., and GAY, A. J. (1959) A.M.A. Arch. Ophthal., 62, 2 I I

BIETTI, G. (1972) Amer. F. Ophthal., 73, 475

BLAXTer, P. L. (1956) Trans. ophthal. Soc. U.K., 76, 15

Bloomfield, s., and Kellerman, L. (1947) Amer. F. Ophthal., 30, 869

DRANCE, s. m. (1960) Arch. Ophthal. (Chicago), 63, 668

- (1963) Ibid., 69, 39

EVANS, J. N. (1942) Ibid., 27, I 177

galin, m. A., Aizawa, F., and malean, J. м. (196r) Amer. F. Ophthal., 52, I5

GLoster, J. (1970) Brit. F. Ophthal., 54, 649 (1965) Arch. Ophthal. (Chicago), 73, 25

LAWrence, C., and WOLFF, s. M. (1962) J. Ophtal. soc., No. $3^{1-32}$, I 5

LEYDHECKER, w. (1950a) Brit. F. Ophthal., 34, 457

(1950b) Ibid., 34, 535

(1954) Ibid., 38, 290

NØRSKOv, K. (1967) Acta ophthal. (Kbh.), 45, 57

PERKINs, E. s. (1973) Brit. F. Ophthal., 57, I 79

RICHARDSON, K. T. (I972) Ibid., 56, 2 I 6

SAIDUZZAFAR, H. (1962) Ibid., 46, 717

SGHeie, H. G., SPENGER, R. W., and HELmick, E. D. (1956) A.M.A. Arch. Ophthal., 56, 797

SPAETH, G. L. (1967) Arch. Ophthal. (Chicago), 77, 50

STEPANIK, J. (1958) Ophthalmologica (Basel), 136, 174

sUgar, H. s. (1948) Amer. F. Ophthal., 31, I 193

SWANLJUNG, H., and BLODI, F. C. (1956) Ibid., 41, 187

YONEBAYASHI, M. (1958) Acta Soc. ophthal. jap., 62, 1454 